\title{
The Impact of Corporate Governance on Earning Management of Non-Financial Firms: Evidence from Pakistan
}

\author{
MUHAMMAD TAHIR KHAN \\ Lecturer, Institute of Business Studies and Leadership \\ Abdul Wali Khan University, Mardan. \\ Email: mtahir@awkum.edu.pk \\ Dr. IHTESHAM KHAN \\ Assistant Professor, Institute of Business Studies and Leadership \\ Abdul Wali Khan University, Mardan. \\ Email: ihtishamkhan@awkum.edu.pk

\section{Dr. SHAH RAZA KHAN} \\ National Bank of Pakistan. \\ Email: Shah.raza@nbp.com.pk
}

\begin{abstract}
The main objective of the firm is to maximize the shareholder's wealth; to achieve this objective the management indulge the earnings information by manipulation practices such practices reduce investors' confidence. Furthermore, a hypothetical dispute recommends that a better quality of financial reporting reduce the information asymmetry, by refining the corporate governance compliance, result in reducing earnings management practices. Thus the main aim of this study is to explore the impact of corporate governance on earnings management by using panel data sample of 257 non-financial firms listed in Pakistan stock exchange for the period of 2012 to 2019 through Fixed effect model along with control variables. The results disclose that the CG system of Pakistan negatively and significantly impacts the EM activities of the companies registered in Pakistan stock exchange. Hence, concludes that the CG system is more effective to prevent the EM process. The entire results are seamless with prior research work that the effective CG scheme of the firms controls the EM and collapse of businesses.
\end{abstract}

Keywords: Earnings Management, Corporate Governance, Corporate Governance Index.

\section{Introduction}

Corporate governance (CG) becomes a critical issue after failure of the largest business such as Xerox, Enron, Parmalat around the world. Such failure reduces the confidence of investors on quality of financial reporting. Further documented that management comprises in obscure the actual economic performance of firms through manipulating earnings. Earnings are the starting point used by investors to take decision whether to invest in the stock of the firm's (Saona et al., 2017). Furthermore, earnings are one of the criteria used to measure the managers' performance and reward is paid.So, business runners manipulate the earnings using different techniques (Shayan-Nia et al., 2017). The manipulation of the financial reports is called earning management (Zhang et al., 2018). Earnings manipulation practices are offered in literature by different terminology such as big bath and window dressing (Stolowy\& Breton, 2004). Earnings management $(\mathrm{EM})$ is defined as: 
"Managers use judgment in financial reporting and in structuring transactions to alter financial reports to either mislead some stakeholders about the underlying economic performance of the company, or to influence contractual outcomes that depend on reported accounting numbers" (Healy \& Wahlen, 1999).

EM practices exaggerate the reports of the company that results inequity in financial system. In conclusion, such practices cause businesses collapse (Habbash, 2010). These Collapses created an international attention on how to systematically implement improved CG practices to prevent fraud and questionable managing of earnings. The company was running a scheme from which it was able to receive huge amounts of illegal deposits. Since the company's fraudulent activities emerged almost 20 years ago, more than twenty-five thousand investors lost their confidence on company financial reporting and still waiting for the recovery of the investments that they made in the company (Dar et al., 2011; Javeed \& Yaqub, 2015). For the purpose to restore the confidence of investors on stock market numerous countries introduced changes by like Sarbanes-Oxley Act 2002 by US government, Malaysian government revisited the governance system and UK also introduced different changes. Furthermore, Pakistan launched corporate governance code 2002 and then CG code 2012 with amendments because of National Bank and Mehran Bank scandal etc... the reasons behind these scandals were due to mismanagement or more specifically, bad governance. In regards to such scandals governance system needs to improve the quality of financial information and restore the confidence of investors on stock market.

In Pakistan, to further improve the CG system like with the advancement in the local and international markets, the codes were revised and re-released in 2012 and further update in 2017.Strong CG system helps in improvement the disclosure of firm fundamentals information. Furthermore, a strong governance system and providing a complete firms financial information help management to decrease the asymmetry information among inside and outside investors, result in reducing EM practices around the world. Based on the above discussion, the purpose of this study is to explore the impact of CG on firm's EM with evidence from non-financial firms operating in Pakistan.

\section{Literature Review}

CG and EM get a serious attention from academician and regulators in recent years because of large numbers of corporate failure around the Globe (Uadiale, 2012). The major reason behind such corporate failure is manipulation in accounting information. Moreover, investors were against the weak CG system. In another study on Turkish companies strong CG practices showed improvement in mala fide EM practices. That further improved the trust level of shareholders on financial system (Turegun\&Kaya, 2016). Furthermore, Lakhal (2015) check 170 firms in France and observed improvement in CG practices in reducing EM in the firms.

Previous accounting research has studied the association among different CG aspects and EM (Peasnell et al., 2005).In addition, Bradbury, Makand Tan (2006) examined the relationship between the board size and earnings management and assert that earnings management has a negative relationship with the size of the board, that is, a large size of the board controls the opportunistic behavior of the management. Even though, board size has gained great attention in the literature and evidence has been put forward for the importance of board size in the reduction of earnings management. However, ignoring other board characteristics as well as audit committee characteristics, external audit quality and ownership structure gives serious concern as these factors are equally important in determining the level of earnings management.

AmerandAbdelkarim (2011) investigate how board independence effect the earnings management practice using sample of 22 listed companies. The result reveal that board independence was positively associated with earnings manipulation. 
Furthermore, the Audit committee (AC) size is another important factors for observing EM. to Xieet al. (2003) documented that AC size is three to four normally, any size that is too small or too large can affect the director performance and monitoring effectiveness (Vafeas, 2005). Previous studies proposed that companies with large AC are more effective in control the management (Alzoubi, 2016). The previous studies which were conducted to examine the association between AC size and accruals EM revealed negative results (Fodio et al., 2013; Juhmani, 2017; Mishra \& Malhotra, 2016). The implication of this result is that larger ACs are better at reducing EM as larger ACs have more resources and capabilities and therefore, are better in performing the required duties.

Further aspect of research explored the relationship among concentrated ownership, CG and EM, the findings illustrate that a company where executives, their family or relatives hold large ownership engage in EM. Their findings also disclose no effect of duality of CEO, audit firm size, board size and impact of ownership meditations on EM (Kamran \& Shah, 2014). Others studies like Klien (2002) inspected the associations among the function of the board and EM. And reported that when audit committee work independently the EM will be decreases and increases the EM when CEO itself member of the board. These consequences propose that the board would be more effective in controlling accounting processes if it is independent from the CEO. A research done by Xie et al. (2003) and recognized the reality that the function of the board of directors plays a crucial role in avoiding the decision makers from earnings manipulation.

Institutional investors are often regarded as sophisticated investors who are better able to acquire and process information than individual investors (Bartovet al., 2000). Institutional ownership (INTO) means that a portion of a firm equity is in the hand of financial institutions and non-financial corporations, which represent both private and public owned institutions. The previous studies which were conducted to analyze the association between INTO and accruals EM revealed negative results (Aygun et al., 2014; Eze, 2017; Memis \& Cetenak, 2012). The results revealed that firms with greater level of INTO have lower EM. This result supports efficient monitoring hypothesis that proposes that large number of institutional investors bring more capital and have abilities to monitor managers than a single individual investor. Other study like KlaiandOmri (2011) explore the correlation among CG and quality of financial reporting in Tunisia by taking Ten years' data of 22 non-financial firms. Results discloses that state and institutional ownership has positive relationship with earnings quality and further documented that public and institutional ownership are effective to restrict the opportunistic performance of managers which is a signal of greater earnings quality.

In Pakistan the analysis about CG and EM relationship needs to be explore. However, a few investigators have attempted to examine this relationship, but they report different outcomes. For instance, Kamran and Shah (2014) explore the consequences of CG and proprietorship concentration on EM. Their outcomes reveal that EM practices improved in that company where board of directors and their family or relatives hold large portion of proprietorship. Further their results show that duality of CEO, Audit size, board size and impact of proprietorship concentrations have no effect on EM. One more study explore the association between CG and EM of listed firm in Pakistan stock exchange. The outcomes of the study conclude that CG and EM have a positive relationship with each other. The author further explains that the reason behind the positive relationship between CG and EM may be due to provisional stage of the 2002 CG code (Shah et al., 2009).

Furthermore, in Pakistan the revised Code of corporate governance 2012 introduced key changes to the governance of firms, particularly in the areas of independent director requirements, board's statements, chief executive officer (CEO) and chief financial officer (CFO) certifications on financial statements, internal and external auditor role and functions and reporting and compliance of the Code. Therefore, research in this particular subject creates a prospective area for further investigation. Thus the aim of this study is to investigate the impact of CG on firms EM with evidence from non-financial firms operating in Pakistan. 


\section{Data and Methodology}

The aim of this study is to explores the impact of CG on firms EM evidence from non-financial firms in Pakistan. The present study population is all non-financial firms listed on Pakistan stock exchange. The availability of Annual reports of large number of companies is a big issue, therefore the sample size of this study is restricted to only 257 non-financial registered firms on Pakistan stock exchange. The period of the study is from 2012 to 2019. Panel and secondary data are used and download from SBP and websites of the companies.

Most of the studies used Abnormal Accruals as a proxy for EM and considered as dependent variable Previous studies show that the existing discretionary accrual measures are miss specified when applied to corporation having extreme performance. For instance, Beslic, jaksicand Andric (2015) explore the credibility influence of the current EM models and they reported that Jones Model, Modified Jones Model and Kasznik Model don't have satisfactory illustrative influence, and also determine that in jones model discretionary accruals and return on assets are absolutely related with each other. Thus, performance matched discretionary accrual (PMDA)model is developed to remove the misspecification problem of previous models (Kothari et al., 2005).

Following is the PMDA model.

$\mathrm{TA}_{\mathrm{it}}=\beta_{\mathrm{o}}\left(1 / \mathrm{A}_{\mathrm{t}-1}\right)+\beta_{1}\left(\Delta \operatorname{Rev}_{\mathrm{it}}-\Delta \mathrm{ARec}_{\mathrm{it}}\right) / \mathrm{A}_{\mathrm{t}-1}+\beta_{2}\left(\mathrm{PPE}_{\mathrm{it}} / \mathrm{A}_{\mathrm{t}-1}\right)+\beta_{3}\left(\operatorname{RoA}_{\mathrm{t}-1}\right)+\varepsilon_{\mathrm{it}}$

Where:

TA, $\mathrm{A}_{\mathrm{t}-1}, \Delta \mathrm{Rev}, \triangle \mathrm{ARec}, \mathrm{PPE}, \mathrm{ROA}_{\mathrm{t}-1}$ and $\varepsilon$ represent Total accruals, total assets lagged value, change in revenue, change in account receivable, property, plant and equipment, return on assets and error term respectively. Furthermore, i indicate firm and $t$ indicate time, thus for measurement of abnormal accruals the above model is used in this study.

The other interest variable is CG. A strong CG mechanism is required to control the discretionary power of firm's management, because most of studies reported that a weak CG provide opportunity for management of the firms to spoil in EM practices. This CGI is the combination of 70 broad set of CG provisions containing Pakistani CG code 2002 and 2012. Further these 70 set of CG Provisions divided in to 5 sub-set i.e., Board of Directors, Committees and Auditing, Shareholders Rights, Transparency and disclosure and Internal Control, External Auditor \& Risk Management. The binary code procedure is used for constructing the CGI and data is taken from firm's annual report, according to this method 1 is awarded to a CG provision if it has been published in annual report of the firms and otherwise 0 .

\section{Control Variables}

In addition to the main variables, previous works provide evidence that recognizes the variables which affect the relationship of EM and CG, such as firm size, Leverage, GDP Growth, Firm age, and firm performance. For example, large firm size affects the board of director's structure due to diversification in firms. Furthermore, large firms have complex operational system which provide opportunity to management to manipulate their earnings. Size of the firm normally measure through log of total assets (Alzoubi, 2016). The second control variable used in this study is leverage, leverage represent capital structure of the firm which is measured as ratio of total debt to total assets (Barghathi, 2014; Xiaoqi, 2013). The other important variable used as a control variable in this study is GDP growth rate. The significant objective of every country has to improve the GDP growth rate and for this purpose each section of the country should need to work efficiently. Furthermore, Rad (2014) explores that commercial sector like corporation and enterprises are significant sector that contribute efficiently to GDP rate. Additional important control variable is firm performance. The management capability is measure through 
performance of the firms, that how efficiently they utilize organization resources. Previous literature i.e., Almasarwah, (2015) and Barghathi, (2014) reported that ROA is used as a proxy for firms' performance. The last control variable used in this study is age. All these control variables effect the EM practices of management empirically as well as theoretically.

\section{Results and Discussion}

The result of descriptive statistical test for the sample companies are given in table 1 which describes Mean, Standard deviation, Minimum, maximum, skewness and kurtosis of all variables used in this study.

Table No: 1

\begin{tabular}{|ccccccc|}
\hline Variables, & Mean & St.Dev & Min & Max & Skewness & Kurtosis \\
\hline AEM & -0.012 & 0.131 & -0.5 & 0.551 & 0.862 & 4.362 \\
CGI & 0.017 & 0.982 & -3.46 & 1.972 & -0.53 & 2.838 \\
Leverage & 3.438 & 0.453 & 1.508 & 4.585 & 0.704 & 4.314 \\
Size & 6.758 & 0.741 & 4.115 & 8.823 & 0.09 & 2.932 \\
GDP Growth & 4.916 & 0.763 & 3.507 & 6.836 & -0.321 & 2.394 \\
age & 35.803 & 15.011 & 2 & 86 & 0.444 & 2.645 \\
ROA & 1.374 & 1.05 & -4.319 & 3.835 & -0.962 & 4.722 \\
\hline
\end{tabular}

Descriptive statistics are used to explore the data nature (Xiaoqi, 2013). Performance match model is used to calculate EM. The mean of EM is -.012 and standard deviation is .131, which is not considerably change from the mean. In addition, the minimum value is -.50 and maximum value .55 . Therefore, this descriptive value of EM demonstrate that all the firms listed in Pakistan stock exchange follow the standard procedure of accounting principle and the management of firms can not involve in earnings management activities. Furthermore, the minimum value of $\mathrm{CG}$ is -3.46 and maximum value is 1.972 . The highest value 1.97 illustrate that the CG application is improved after the implementation of corporate governance code. The mean and standard deviation values are very close to each other; therefore, the implementation mechanisms of CG are same usually. Furthermore, descriptive of leverage illustrate that firms taken for the study depends on debt financing. In addition, the result show Size of the sample firms are not too different. Furthermore, the GDP growth rate descriptive value shows a positive indicator of the market. In addition, ROA the mean value of ROA is 1.374 and Standard deviation is 1.05, maximum and minimum value is 4.319 and 3.835 respectively, which demonstrate that ROA perform positively for given sample of firms.

\section{Correlation Result}

Table.2: Correlation Results

\begin{tabular}{|lccccccr|}
\hline & AEM & CGI & Leverage & Size & GDP Growth & Age & ROA \\
\hline AEM & 1.0000 & & & & & & \\
CGI & -0.0085 & 1.0000 & & & & & \\
Leverage & -0.0273 & -0.0575 & 1.0000 & & & & \\
Size & 0.1998 & 0.1274 & -0.0845 & 1.0000 & & & \\
GDP Growth & 0.0922 & 0.2084 & -0.0287 & 0.0893 & 1.0000 & & \\
age & 0.0587 & 0.0500 & -0.0616 & -0.0025 & 0.1323 & 1.000 & \\
ROA & 0.0456 & 0.0743 & -0.1091 & 0.0933 & -0.0675 & -0.0264 & 1.000 \\
\hline
\end{tabular}

Table 2 shows the correlation coefficients between dependent variable i.e., earnings management with independent variables i.e., CG and control variables such as leverage, size, GDP growth rate, age and ROA. EM is negatively associated with CG and leverage. These results consistent with the study done by Tanjung 
et al., (2015) and Turegun\& Kay(2016). The negative relationship between EM and CG illustrate that efficient CG mechanism implementation reduce the earnings manipulation practices. However, the association of Size, GDP growth, age and ROA is positive with EM this reveals that the large firms size is extremely involve in EM activities.

\section{Hausman Test Result}

Table. 3: Results of Model Selection

\begin{tabular}{|lcc|}
\hline Models & Test Value & P-Value \\
\hline F-Test Results & 12.15 & 0.00 \\
F- Value & & 0.03 \\
Hausman Test chi2 $(6)=(b-B)^{\prime}\left[\left(V_{-} b-V_{-} B\right)^{\wedge}(-1)\right](b-$ & 13.75 & \\
B) & & \\
\hline
\end{tabular}

Table 3 shows the Hausman test result, prior to explain the empirical result the study applied the hausman test to select the model among fixed and random effect model. The finding of hausman test illustrate that Chi-sq statistics value is significant at $5 \%$ level, which shows that Fixed effect analysis is suitable for given model.

\section{Results of Panel Data Analysis}

Table. 4: Fixed Effect Model (FEM) results Dependent Variable (AEM)

\begin{tabular}{|cccc|}
\hline Variables & Coefficient & t-Value & P-value \\
\hline Constant & -0.5426556 & -7.07 & 0.000 \\
CGI & -0.0113435 & -3.18 & 0.002 \\
Leverage & 0.0163704 & 1.50 & 0.135 \\
Size & 0.0575764 & 6.45 & 0.000 \\
GDPGrowth & 0.0154088 & 3.69 & 0.000 \\
age & 0.0001361 & 0.29 & 0.774 \\
ROA & 0.0012251 & 3.55 & 0.000 \\
\hline
\end{tabular}

Table above present the result of FEM for exploring the effect of CG on firms EM for the period 2012 to 2019. The result depict that CG is negatively associated with EM for given sample firms listed in Pakistan stock exchange. These finding consistent with previous studies like Ilyas et al., (2017) and Tanjungetal., (2015). Additionally, Paiva\& Lourenco (2013) and Ishak et al. (2011) conclude that businesses owned by family members are less engaged in EM activities. Hence, conclude that in Pakistan mostly businesses are retained by big families and they cannot spoil in EM activities because of protected their family status. Furthermore, ROA, leverage, GDP growth, age and size are used as control variables. The result shows that most of the control variable have positive association with EM like leverage coefficient is 0.016 , size is 0.05 , GDP growth is 0.015 , age is .000 and ROA is 0.001 and all are in expected according to theory. Moreover, when companies sustain larger levels of liability are more aggressively exercised earnings manipulation. These results depict that companies involve in more accruals based EM when increases their liability, which means that companies exaggerate the financial information's to achieve the prescribed agreements. Furthermore, performance of the firm in term of ROA, GDP growth are significantly associated with EM. Managers see themselves encouraged to manipulate the statements to achieve this estimated performance evaluated through ROA(Mellado, C.,\& Saona. P., 2019).

Furthermore, the study documented that there is positive and significant association among firm size and EM activities. In other words, that large size of companies mostly involves in manipulation their financial information because identifying EM in financial information of large size firms is probable to be difficult 
(Lobo \& Zhou, 2006). In conclusion, that according to the adjusted R-square of the model which is $10.26 \%$ and the F-statistics value shows that the model is significant at $5 \%$ level (p-value $<0.05)$.

\section{Conclusion}

This research work explores the association among CG and EM of 257 non-financial firms listed in Pakistan stock exchange. The proxy is used for corporate governance is CGI the combination of 70 broad set of CG provisions containing Pakistani CG code 2002 and 2012 adopted from Khan M. Yar (2016) and earnings management is calculated from performance match model developed by Kothari et al., (2005). In addition, numerous control variables are used in this study. Panel data techniques are used for data analysis based on diagnostic test decide that FEM is appropriate. The results disclose that the CG system of Pakistan negatively and significantly effects the practices of earnings manipulation of registered firms in Pakistan stock exchange. Hence, conclude that the corporate governance structure is effectual to restrain the EM practice.

\section{References}

Abbad, S., Hijazi, Q., \& Al-Rahahleh, A. (2016). Corporate governance quality and earnings management: Evidence from Jordan. Australasian Accounting, Business and Finance Journal, 10(2), 54-75.

Almasarwah, A. (2015). Earnings management and its relationship with corporate governance mechanisms in Jordanian industrial firms. (Doctoral dissertation). Loughborough University: UK

Alzoubi, E. S. S., \&Selamat, M. H. (2016). The effectiveness of corporate governance mechanisms on constraining earning management: Literature review and proposed framework. International Journal of Global Business, 5(1), 17-35.

Aygun, M., Ic, S., \&Sayim, M. (2014). The Effects of Corporate Ownership Structure and Board Size on Earnings Management: Evidence from Turkey. International Journal of Business and Management, 9(12), 123-132.

Barghathi, Y. M. B. S. (2014). Perceptions of earnings management in Libyan Commercial Banks. (Doctoral dissertation). University of Dundee: Scotland

Bartov, E., Gul, F.A., \&Tsui, J.S.L. (2000). Discretionary-accruals models and audit qualifications. Journal of Accounting and Economics 30 (3), 421-452.

Beasley, M. S. (1996). An empirical analysis of the relation between the board of director composition and financial statement fraud. The Accounting Review, 71(4), 443-465.

Beneish, M. D. (1997). Detecting GAAP violation: Implications for assessing earnings management among firms with extreme financial performance. Journal of Accounting and Public Policy, 16(3), 271-309.

Beslic, I., Beslic, D., Jaksic, D., \& Andric, M. (2015). Testing the models for detection of earnings management. Industrije, 43(3), 55-79.

Bradbury, M., Mak, Y. T., \& Tan, S. M. (2006). Board characteristics, audit committee characteristics and abnormal accruals. Pacific Accounting Review, 18(2), 47-68.

Brickley, J. A., Coles, J. L., \& Terry, R. L. (1994). Outside directors and adoption of Poison pills. Journal of financial Economics, 35(3), 371-390.

Dar, L. A., Naseem, M. A., Rehman, R., \& Niazi, G. S. K. (2011). Corporate Governance and Firm Performance: A Case Study of Pakistan Oil and Gas Companies Listed in Karachi Stock Exchange. Global Journal of Management and Business Research, 11(8), 1-11.

Dechow, P., Ge, W., \& Schrand, C. (2010). Understanding earnings quality: A review of the proxies, their determinants and their consequences. Journal of Accounting and Economics, 50(2-3), 344-401.

Dechow, P. M., Sloan, R. G., \& Sweeney, A. P. (1996). Causes and consequences of earnings manipulation: An analysis of firms subject to enforcement actions by the SEC. Contemporary Accounting Research 13(1), 1-36

Dechow, P.M., Sloan, R.G. \& Sweeney, A.P. (1995), "Detecting earnings management", The Accounting Review, 70(2), 193-225. 
Eze, I. O. (2017). Corporate Governance Mechanisms and Earnings Management in Nigerian Food Product Companies. Journal of Administrative and Business Studies, 3(1), 1-9.

Fodio, M. I., Ibikunle, J., \& Oba, V. C. (2013). Corporate governance mechanisms and reported earnings quality in listed Nigerian insurance firms. International Journal of Finance and Accounting, 2(5), 279286.

Habbash, M. (2010). The effectiveness of corporate governance and external audit on constraining earnings management practice in the UK. (Doctoral dissertation). Durham University. England.

Healy, P. M., \&Wahlen, J. M. (1999). A review of the earnings management literature and its implications for standard setting. Accounting Horizons 13, 365-383.

Ilyas, M., Ahmad, A., Khan, I., \& Khan, M. T. (2018). The impact of corporate governance on earnings management: Empirical evidence from Pakistan. Journal of Research in Social Sciences, 6(2), 256271.

Ishak, I., Haron, M. N., Salleh, N. M. Z., \& Rashid, A. A. (2011). Family control and earnings management: Malaysia evidence. ( $2^{\text {nd }}$ International Conference on Economics, Business and Management, Singapore. Retrieved from researchgate.net/ publication/260791905.

Javeed, A., \&Yaqub, R. M. (2015). An Empirical Examination of the Impact of Corporate Governance Measures and Capital Structure on Firm Profitability in Pakistan. Research Journal of Finance and Accounting, 6(13), 9-16.

Johnson, S., Boone, P., Breach, A., \& Friedman, E. (2000). Corporate governance in the Asian Financial Crisis. Journal of Financial Economics, 58,141-186

Jones, J. J. (1991). Earnings management during import relief investigations. Journal of Accounting Research, 29(2), 193-228.

Kamran \& Shah, A. (2014). The impact of corporate governance and ownership structure on earnings management practices: Evidence from listed companies in Pakistan. The Lahore Journal of Economics, 19(2), 27-70.

Khan, Muhammad Yar (2016). Corporate governance and cost of capital: evidence from Pakistani listed firms. (Doctoral dissertation). University of Glasgow, UK

Klai, N., \&Omri, A. (2011). Corporate governance and financial reporting quality: The case of Tunisian firms. International Business Research, 4(1), 158.

Klein, (2002). Audit committee, board of director characteristics, and earnings management. Journal of Accounting and Economics 33, 375-400.

Korkmaz, A. G. (2015). Three Essays on Corporate Governance. Cleveland State University.

Kothari, S. P., Leone, A. J., \&Wasley, C. E. (2005). Performance matched discretionary accrual measures. Journal of Accounting and Economics 39, 163-197.

La Porta, R., Lopez-De-Silanes, F., Shleifer, A., \& Vishny, R. W. (1997). Legal determinants of external Finance. The Journal of Finance, LII (3), 1131-1150

Lakhal, N. (2015). Corporate disclosure, ownership structure and earnings management: The case of French-listed firms. The Journal of Applied Business Research, 31(4), 1493-1504.

Lee, J. (2006). Family firm performance: Further evidence. Family Business Review, XIX (2), 103-114.

Lobo \& Zhou. (2006). Did Conservatism in Financial Reporting Increase after the Sarbanes-Oxley Act? Initial Evidence. Accounting Horizons 20 (1), 57-73.

Mellado, C., \&Saona, P. (2019). Real earnings management and corporate governance: a study of Latin America. Economics Research, 33(1), 2229-2268.

Paiva, I., \& Lourenco, I. (2013). The effect of size on the level of earnings management in family firms. Available at SSRN: https://ssrn.com/abstract=2286757.

Peasnell, K.V., Pope, P., \&Young, S. (2005). Board monitoring and earnings management: Do outside directors influence abnormal accruals? Journal of Business Finance \& Accounting, 32(7-8), 13111346.

Rad, S. A. (2014). The relationship between corporate governance practices and cost of capital in large listed companies of New Zealand and Singapore. Retrieved http://researchcommons.waikato.ac.nz/. 
Shah, S. Z. A., Butt, S. A., \& Hassan, A. (2009). Corporate governance and earnings management an empirical evidence from Pakistani listed companies. European Journal of Scientific Research, 26(4), 626-638.

Shayan-Nia, M., Sinnadurai, P., Mohd-Sanusi, Z., \& Hermawan, A.-N. A. (2017). How Efficient Ownership Structure Monitors Income Manipulation? Evidence of Real Earnings Management among Malaysian Firms. Research in International Business and Finance, 41(1), 54-66.

Stolowy, H., \& Breton, G. (2004). Accounts manipulation: A literature review and proposed conceptual framework. Review of Accounting and Finance, 3(1), 5-92.

Tanjung, M., Sucherly, Sutisna, \& Sudarsono, R. (2015). The role of good corporate governance in minimizing earning management to increase value of firm. International Journal of Scientific \& Technology Research, 4(9), 21-27.

Turegun, N., \& Kaya, C. T. (2016). Revisiting the association between corporate governance and earnings management. Journal of Accounting, Finance and Auditing Studies 2(2), 115-127.

Uadiale, O. M. (2012). Earnings management and corporate governance in Nigeria. Research Journal of Finance and Accounting, 3(3), 1-10.

Vafeas, N. (2005). Audit committees, boards, and the quality of reported earnings. Contemporary Accounting Research, 22(4), 1093-1122.

Xiaoqi, S. (2013). Earnings management, Tunneling behavior and corporate governance: The case in China. Durham University. UK. Available at Durham E-Theses Online: http://etheses.dur.ac.uk/9414/

Xie, B., Davidson, W. N., \&DaDalt, P. J. (2003). Earnings management and corporate governance: The role of the board and the audit committee. Journal of Corporate Finance 9, 295-316.

Zhang, Y., Perols, J., Robinson, D., \& Smith, T. (2018). Earnings management strategies to maintain a string of meeting or beating analyst expectations. Advances in Accounting, 43, 46-55.
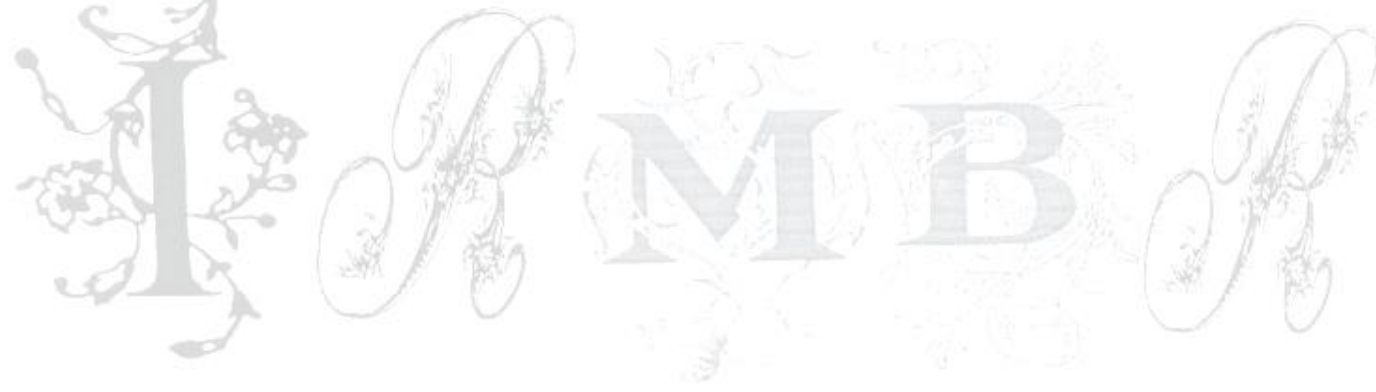